\title{
THE ESTIMATION OF 5-HYDROXYTRYPTAMINE IN THE PRESENCE OF ADRENALINE
}

\author{
BY \\ JEAN D. GARVEN \\ From the Department of Pharmacology, University of Edinburgh
}

(RECEIVED OCTOBER 31, 1955)

Recently Amin, Crawford, and Gaddum (1954) developed a method for the extraction and estimation of 5-hydroxytryptamine (HT) which depended for assay on responses evoked in the isolated oestrous uterus of the rat. This preparation is sensitive to inhibition by adrenaline and noradrenaline, and it was appreciated that in some tissues there could be sufficient of these to make the HT estimate too low. The present study aimed at eliminating errors due to either adrenaline or noradrenaline in the estimation of HT in various tissues of the rabbit.

An attempt was made to separate HT from adrenaline by paper chromatography, elute the HT from the appropriate strip, and estimate the activity on the oestrous uterus of the rat-but a satisfactory method was not developed. Later, assays were based on vasoconstriction in the isolated perfused ear of the rabbit, where the aim was to minimize the effects of adrenaline and noradrenaline by the use of specific antagonists. But this method was very tedious, and was abandoned.

It was found that the inhibitory effect of adrenaline could be eliminated by the use of the polyphenoloxidase enzyme present in mushroom juice. So all the tissue extracts were treated with a standard preparation of crude mushroom juice before they were assayed on the fairly regular and sensitive isolated atropinized oestrous uterus of the rat.

\section{MeTHods}

The. Isolated Rat Uterus-Method for Assay.Erspamer first used the atropinized oestrous uterus of the rat for the assay of enteramine, or HT (Erspamer, 1942, 1952). The method of Amin, Crawford, and Gaddum (1954) for the preparation of the uterus in oestrus and its use for the assay of HT was employed here. Doses of 5-20 ng. HT (in a $2 \mathrm{ml}$. bath) gave suitable responses, magnified 10-12 times, with a discrimination of $\pm 1-2 \mathrm{ng}$. for the estimations. A sample of 5-hydroxytryptamine creatinine sulphate was supplied through the courtesy of Upjohn Laboratories, Kalamazoo, Michigan.

At the end of each series of assays the rat uterus preparation was treated with lysergic acid diethyl- amide (LSD). This caused specific blockade of the response to HT (Gaddum, 1953). The effect of the tissue extracts was again tested on the uterus.

Sampling of the Rabbit Tissues.-Since clotted rabbit blood has a high HT equivalent (Erspamer, 1954a, b), efforts were made to remove as much blood as possible from the tissues before sampling. A rabbit was anaesthetized with ether, and its aorta was cannulated ; perfusion of about $1 \mathrm{l}$. of isotonic saline was made at about $60 \mathrm{~cm}$. water pressure. Blood and perfusate were allowed to escape through an opening in the inferior vena cava.

When samples from the head and neck were required the carotid arteries were cannulated and the perfusate allowed to escape by the jugular veins. The pulmonary artery was cannulated when lung samples were required. In one case where this was done a series of samples of perfusate was collected throughout the perfusion. They were later calibrated colorimetrically in terms of the first sample. This showed that when the tissue was creamy-white and appeared bloodless, and the perfusate was almost colourless, the latter contained less than $1 \%$ of blood. No oedema was apparent.

When the perfusate was almost colourless, samples of tissue were taken, weighed, and extracted. If there was any delay in the dissection, e.g., while the skull was being opened for the brain, any other tissue samples already collected were stored at $-17^{\circ} \mathrm{C}$.

On two occasions, after the perfusion was complete, electrodes were placed on the spleen, and stimulation was applied until the organ was quite contracted. It was then removed, weighed, and extracted.

In sampling the gut mucosae the whole stomach and intestines were removed and separated into stomach, upper half of the small intestine, lower half of the small intestine, and large intestine. Each portion was slit open throughout its length and washed under running tap-water. When clean it was blotted dry with filter paper. The whole mucosa of each area was scraped gently off with a blunt scalpel, weighed, and extracted; then an aliquot of the acetone extract was taken.

Method of Extraction of Tissue Samples.-Amin (1953) and Amin et al. (1954) have studied the quantitative extraction of HT from horse intestine. They found that the best results were obtained with a double 
extraction of the tissues with acetone- -the first extraction with $20 \mathrm{ml}$. A.R. acetone/g. tissue, and the second with $20 \mathrm{ml} .95 \%$ acetone/g. tissue.

This removed all the extractable HT in solution in the acetone and left the substance $P$ in the insoluble residue.

In detail the use of this method here was as follows. The samples, on removal from the rabbit, were placed in weighing bottles, or the larger ones on watch glasses, and weighed. The latter were then removed to beakers. Twenty volumes of A.R. acetone was added to each, and the tissue finely divided with scissors, and pressed and stirred occasionally with a flattened glass rod for $1 \mathrm{hr}$. Tough or dense tissues, such as skeletal muscle, diaphragm, and heart, were cut up under the acetone and then rubbed in a mortar with silver sand. The supernatant fluid was filtered through a Whatman No. 1 paper, which had been washed with $5 \mathrm{ml} .95 \%$ acetone. When filtration was complete the papers were each washed with $2 \mathrm{ml} .95 \%$ acetone. To each of the residues was added 20 volumes of $95 \%$ acetone ; these were again stirred and pressed for half an hour. The supernatant fluids were filtered, each through the same paper as before. The bottle, or beaker, and the precipitate were washed twice with $5 \mathrm{ml} .95 \%$ acetone, and the combined acetone filtrates and washings were evaporated to dryness, under reduced pressure at 30$35^{\circ} \mathrm{C}$., $2 \mathrm{ml}$. ethanol being added when necessary to reduce frothing. One $\mathrm{ml}$. of water was added to each residue, and the solution was extracted twice with 10 $15 \mathrm{ml}$. of light petroleum (b.p. $40-60^{\circ}$ ) to remove lipids. The aqueous residue was evaporated to dryness under reduced pressure at $30-35^{\circ} \mathrm{C}$. The extracts were stored overnight at $-17^{\circ} \mathrm{C}$. and assayed on the next day.

Samples of blood, obtained from rabbits under ether or urethane anaesthesia, were extracted with 20 volumes of A.R. acetone; after having been thoroughly shaken, the flasks were stored at $5^{\circ} \mathrm{C}$. for half an hour. The extracts were filtered through acetone-washed papers, and the flasks and precipitates washed with $95 \%$ acetone as before. Extraction of the residues with $95 \%$ acetone was considered unnecessary. The evaporation and removal of the lipids was done as with the other samples. Serum, which was centrifuged from blood which had been allowed to clot at room temperature, was similarly extracted.

Preparation of the Mushroom Juice.-The acetone extracts of tissues are likely to contain some adrenaline or noradrenaline, which may interfere with the assay of their HT content. Adrenaline and noradrenaline are ortho-dihydroxy compounds, and HT has a mono-hydroxy structure. Thus it was thought that an enzyme preparation which specifically oxidized dihydroxy compounds could be used for the routine treatment of the extracts before their assay.

Keilin and Mann (1938) detailed the preparation and purification of a polyphenoloxidase from edible mushrooms, and investigated its nature and properties. They stated that even a crude extract of mushrooms oxidized with great velocity, mainly ortho-dihydroxyphenols, and but few monophenols. This difference in oxidation rate was largely due to a protracted lag period. The polyphenoloxidase, which is known also as tyrosinase (Sumner and Myrbäck, 1951 ; Sumner and Somers, 1953), occurs in bacteria, potatoes, and mushrooms, as well as in human skin and melanomata. It is an aerobic oxidase, containing copper, which converts catechol to $o$-quinone as the first step in the formation of melanin.

In the present work, edible mushrooms (Psalliota campestris) were chosen as a convenient source of the enzyme ; they are easily available, and are free from the large quantities of starch which are present in the cheaper source, potatoes. $120 \mathrm{~g}$. of fresh mushrooms were sliced and then ground in a household mincer. The pulp was rubbed in a mortar with about $10 \mathrm{~g}$. of silver sand for $20 \mathrm{~min}$. The juice was squeezed out through linen by hand. This yielded $80 \mathrm{ml}$. of a dark brown turbid fluid, which was slightly frothy. After storage at $5^{\circ} \mathrm{C}$. overnight (reported by Keilin and Mann (1938) often to cause an increase in activity), it was distributed as $0.5 \mathrm{ml}$. samples in small test-tubes. These samples were freeze-dried by reduced pressure in a centrifuge over phosphorus pentoxide.

When the juice was completely dry the tubes were sealed and stored at $5^{\circ} \mathrm{C}$. The residue was like a solid foam and was brown in colour. This redissolved readily to give a slightly turbid solution, which was diluted to $5 \mathrm{ml}$., and $0.25 \mathrm{ml}$. of this, " the enzyme preparation," was added to every $1.0 \mathrm{ml}$. of tissue extract.

Tests of enzyme activity were always based on the time taken for a given amount of enzyme preparation to eliminate the inhibitory effect of a certain amount of adrenaline, or noradrenaline, on the spasm of rat oestrous uterus caused by HT. For the treatment of tissue extracts some of the enzyme preparation was added to the aqueous solution of the acetone extract residue, and these were allowed to stand together at room temperature for at least $\mathbf{4 0} \mathrm{min}$., then an assay of the HT activity was made in the usual way. The $p \mathrm{H}$ of the samples was always between 4.5 and 6.0.

\section{RESULTS}

The Action of the Mushroom Juice.-In the experiment shown in Fig. 1, regular responses to 10.ng. of HT were recorded. Each dose was left in contact with the tissue for $45 \mathrm{sec}$., and $4 \mathrm{~min}$. elapsed between doses. At C, $10 \mathrm{ng}$. of HT was again given, but within the same dose volume there was also $10 \mathrm{ng}$. of adrenaline. The presence of the adrenaline caused inhibition of the response, and the inhibitory effect continued and gradually disappeared as the following responses to $10 \mathrm{ng}$. HT (alone) were recorded.

The solution M contained $100 \mathrm{ng}$. HT, $100 \mathrm{ng}$. adrenaline and $0.20 \mathrm{ml}$. of the enzyme preparation in each $\mathrm{ml}$. The first dose of $\mathrm{M}$, containing $10 \mathrm{ng}$. of each drug, was given $2 \mathrm{~min}$. after the addition 


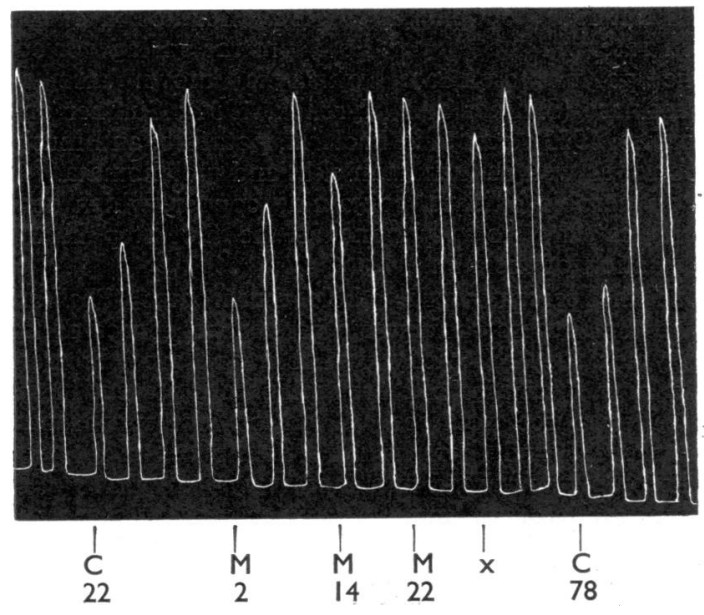

Fig. 1--Rat oestrous uterus in $2 \mathrm{ml}$. bath. Responses to $10 \mathrm{ng}$. HT. At C, 10 ng. HT +10 ng. adrenaline. At M, 10 ng. HT + 10 ng. adrenaline + mushroom juice. Numerals below $C$ and $M$ indicate time in min. from preparation of mixture. At x, $8 \mathrm{ng}$. HT.

of the enzyme preparation, and the inhibition and recovery of the responses was similar to that recorded for the dose $\mathrm{C}$. Then another dose of $\mathrm{M}$, now $14 \mathrm{~min}$. from its preparation, was given. This caused a less inhibited response, and no inhibition of the following doses of $10 \mathrm{ng}$. HT. At $22 \mathrm{~min}$. from preparation, $M$ did not show any inhibitory effect, whereas the action of the sample without enzyme was as before (see $\mathrm{C}$ at $78 \mathrm{~min}$.).

Thus, by standing at room temperature, the enzyme preparation was able to abolish in $22 \mathrm{~min}$. the inhibitory effect of $10 \mathrm{ng}$. adrenaline on the uterine contraction caused by $10 \mathrm{ng}$. HT. It was found also that the enzyme had no effect on the responses to HT alone, unless the preparation and the drug were allowed to be in contact for more than $80 \mathrm{~min}$., when the HT response became slightly reduced.

The results of further experiments showed that the inhibitory effect of adrenaline, when present in concentrations up to ten times that of the HT, could be abolished always within $40 \mathrm{~min}$. from addition of the enzyme preparation. Under similar conditions, noradrenaline in concentrations up to one hundred times that of the HT was also inactivated.

Estimates of HT in the Tissues of Rabbits.Using the acetone extraction method for the samples of tissues, and the treatment of the extracts with the enzyme preparation for at least 40 min., and not more than 80 min., the estimates of the HT activity were made by assay on the atropinized oestrous uterus of the rat. In most cases, analyses of tissues from three or more animals were carried out, in order to obtain some indication of the extent of the individual variation.

The results are given in Table $I$.

\section{TABLE I}

HT EQUIVALENT IN $\mu$ G./G. RABBIT TISSUE

(Where extract activity was not abolished by LSD, estimates are given in parentheses)

\begin{tabular}{|c|c|c|c|}
\hline \multicolumn{2}{|c|}{ Sample } & Individual Estimates & Mean \\
\hline $\begin{array}{l}\text { Spleen: } \\
\text { Unstimulated } \\
\text { Stimulated }\end{array}$ & $\ldots$ & $\begin{array}{l}21 \cdot 0,13 \cdot 8,11 \cdot 1,9 \cdot 1,7 \cdot 7,7 \cdot 6 \\
13 \cdot 3,9 \cdot 1\end{array}$ & $\begin{array}{l}11.7 \\
11.2\end{array}$ \\
\hline $\begin{array}{l}\text { Mucosae: } \\
\text { Stomach } \\
\text { Upper small i } \\
\text { Lower small i } \\
\text { Large intestin }\end{array}$ & $\begin{array}{l}\text { intestine.. } \\
\text { ntestine.. } \\
\text { le } \quad .\end{array}$ & $\begin{array}{l}7 \cdot 5,6 \cdot 4,4 \cdot 6 \\
4 \cdot 0,1 \cdot 4,1 \cdot 2 \\
3 \cdot 7,0 \cdot 67,0 \cdot 52 \\
4 \cdot 0,3 \cdot 5,3 \cdot 0\end{array}$ & $\begin{array}{l}6 \cdot 2 \\
2 \cdot 2 \\
1 \cdot 6 \\
3 \cdot 5\end{array}$ \\
\hline $\begin{array}{l}\text { Brain: } \\
\text { Hypothalamu } \\
\text { Mid-brain } \\
\text { Olfactory bull } \\
\text { Cerebellum }\end{array}$ & $\stackrel{.}{\mathrm{bs}}$ & $\begin{array}{l}0.42,0.40,0.36 \\
0.50,(0.49), 0.13 \\
0.21,0.14,(0.04) \\
(0.05), 0.04,0.03\end{array}$ & $\begin{array}{l}0.39 \\
0 \cdot 31 \\
0 \cdot 17 \\
0.035\end{array}$ \\
\hline $\begin{array}{l}\text { Liver: } \\
\text { Without porta } \\
\text { With " }\end{array}$ & al perfusion & $\begin{array}{l}1.45,0.90,0.48 \\
(0.44),(0.25),(0.13)\end{array}$ & $(0.27)$ \\
\hline Bone marrow & .. & $0.39,0.30,0.29$ & $\mathbf{0 . 3 3}$ \\
\hline $\begin{array}{l}\text { Lung: } \\
\text { With direct } p \\
\text { perfusion } \\
\text { Without direc } \\
\text { ary perfusio }\end{array}$ & $\begin{array}{l}\text { ulmonary } \\
\text { on pulmon- } \\
\text { on } \quad .\end{array}$ & $\begin{array}{l}(0.32), 0.23,0.16,0.12,0.03 \\
0.30,0 \cdot 16,0.07\end{array}$ & $\begin{array}{l}0 \cdot 13 \\
0 \cdot 18\end{array}$ \\
\hline $\begin{array}{l}\text { Thyroid ... } \\
\text { Pancreas } \\
\text { Diaphragm } \\
\text { Salivary glands } \\
\text { Thymus ... } \\
\text { Heart } \quad \ldots \\
\text { Bladder . } \\
\text { Kidney } \\
\text { Skeletal muscle } \\
\text { Sciatic nerve } \\
\text { Adrenal glands }\end{array}$ & 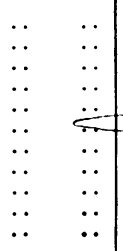 & $\begin{array}{l}(0.23), 0.09 \\
0.21,(0.08), 0.05 \\
0.18,0.12,0.04,<0.02 \\
0.13,0.07,0.06,<0.03 \\
0.05,0.05 \\
0.04,0.03,<0.02 \\
0.13,0.11,0.03 \\
0.15,0.10,0.02 \\
\text { Not detected } \\
" \quad " \quad " \\
" \quad ",\end{array}$ & $\begin{array}{l}0.09 \\
0.13 \\
0.09 \\
0.07 \\
0.05 \\
0.023 \\
0.09 \\
0.09\end{array}$ \\
\hline
\end{tabular}

One series of rabbit tissue extracts was assayed both before and after treatment with the enzyme preparation. The increases in the HT equivalents are shown in Table II. No increase was found with serum-normal serum is unlikely to contain significant amounts of adrenaline or noradrenaline. In this experiment none of the extracts gave any response after the uterus preparation was treated

TABLE II

HT EQUIVALENTS ( $\mu$ G./G.) OF ACETONE EXTRACTS OF RABBIT TISSUES BEFORE AND AFTER TREATMENT WITH MUSHROOM JUICE

\begin{tabular}{lll|l|l|l}
\hline \multicolumn{2}{r|}{ Tissue } & & Before & After & Ratio \\
\hline Kidney & $\ldots$ & $\ldots$ & 0.020 & 0.025 & 1.25 \\
Lung & $\ldots$ & $\ldots$ & 0.060 & 0.075 & 1.25 \\
Pancreas & $\ldots$ & 0.145 & 0.210 & 1.45 \\
Liver & $\ldots$ & $\ldots$ & 0.560 & 0.90 & 1.6 \\
Serum & $\ldots$ & $\ldots$ & 4.40 & 4.40 & 1.0 \\
\hline
\end{tabular}


with lysergic acid diethylamide, so the increase is probably due to an unmasking of more HT activity.

\section{Discussion}

At the beginning of this study on the HT content of acetone extracts of rabbit tissues, it was appreciated that some, at least, of the extracts might contain sufficient adrenaline to cause the estimates on the isolated rat uterus to be too low. This effect was abolished by the use of the polyphenoloxidase present in mushrooms.

Mushroom Polyphenoloxidase.-The enzyme in crude mushroom juice proved very suitable for the destruction of the inhibitory activity of adrenaline on the rat uterus in mixtures of adrenaline and HT. The enzyme preparation was easy to use, since it is active at $p \mathrm{H} 4-6$, which was the reaction of the extracts, and since it is active at room temperature.

The juice contains both polyphenoloxidase and monophenoloxidase. Fortunately for my purpose, the lag time before the monophenoloxidase had its maximum action was such that the adrenaline present was oxidized by the polyphenoloxidase before the monophenoloxidase attacked the HT. By measurement of the oxygen uptake and the loss of biological activity, Philpot (1940) showed a conversion of over $95 \%$ of adrenaline to adrenochrome by a preparation of polyphenoloxidase from mushrooms.

The HT Equivalent of Rabbit Tissues.-The HT equivalent for rabbit blood is high, compared with that for other animals (Erspamer and Faustini, 1953 ; Erspamer, 1954a, b), so that the blood had to be removed, so far as possible, from the tissues before sampling. This was done with an isotonic saline perfusion, and was complete in about 15 or $20 \mathrm{~min}$. The perfusion may also have washed some HT out of the tissues themselves, but this is thought unlikely. Another danger, possibly incurred by this perfusion treatment, is that of causing oedema of the tissues, in which event the HT equivalent determined per gram of sample would be low. There was no evidence of oedema to naked eye inspection, except in one sample of thyroid and one of submaxillary glands, which were rejected. The lung tissue invariably floated in the acetone.

When the perfusate was almost colourless it contained less than $1 \%$ of blood. Thus if a $2 \mathrm{~g}$. sample of tissue were to contain $1 \mathrm{ml}$. of this perfusate, the "blood HT" content of this sample would not be more than $0.025 \mu \mathrm{g}$. (rabbit blood contains 2.0-2.5 $\mu \mathrm{g}$. HT/ml.). The tissue HT equivalents were considered to be significant when they were more than $0.1 \mu \mathrm{g}$. $/ \mathrm{g}$.

The estimate of HT in rabbit blood was $2.0-2.5$ $\mu \mathrm{g} . / \mathrm{ml}$. whole blood and $4.4 \mu \mathrm{g} . / \mathrm{ml}$. serum, from acetone extracts in each case. The HT equivalent given by Erspamer and Faustini (1953) for rabbit serum is $3.53 \mu \mathrm{g} . / \mathrm{ml}$. Another result is given by Erspamer and Sala (1954): it is $4.3 \mu \mathrm{g} . / \mathrm{ml}$. serum, from ten samples. Humphrey and Jaques (1954) give a value of $5.2 \mu \mathrm{g}$. HT $/ \mathrm{ml}$. whole blood which is high compared with these other estimates. Using a chemical method involving the fluorimetric estimation of HT in an extract of platelets, Udenfriend and Weissbach (1954) find $4.0 \mu \mathrm{g}$. $\mathrm{HT} / \mathrm{ml}$. whole blood.

A high HT equivalent was found for the spleen, though the mean estimate was lower than that found by Erspamer. This discrepancy is possibly due to the blood content of the spleens sampled by Erspamer (1954a, b). In the present work the contraction of the spleen caused by electrical stimulation and leading to the expulsion of perfusion fluid from the sinuses caused no significant difference in its HT equivalent.

The values for HT in the mucosae of the various areas of the intestinal tract correspond approximately to those of Erspamer (1954a and b).

Using the atropinized rat colon for assays, Feldberg and Toh (1953) obtained higher HT equivalents for acetone extracts of rabbit gastric mucosa ; fundic mucosa yielded 7.5-10 $\mu \mathrm{g}$. HT/g. and pyloric mucosa $1.25 \mu \mathrm{g}$. HT/g. Yet the relatively high HT content throughout these samples of mucosa is consistent with their high content of enterochromaffin (argentaffin) cells.

The bone marrow had a fairly constant significant content of HT, but it would be difficult to say whether this was due entirely to that in the platelets of the blood passing through the vascular sinuses, or whether part of it was due to HT in the megacaryocytes (already synthesized for the time when these cells break down to form platelets).

When the liver was perfused with isotonic saline, through the portal vein as well as through the aorta, the HT equivalent of the samples was lower than when perfusion was through the aorta only. The most likely reason for this difference is that in the second case some blood was held in the portal sinuses. A volume of $0.25 \mathrm{ml}$. blood per gram of the tissue would contribute $0.5 \mu \mathrm{g}$. HT/g. sample. The proportion, 1 to 3 , of portal blood to liver tissue is perhaps rather high, but it may be that, though less blood is present, excess of platelets is trapped in the tissue spaces before 
destruction by the liver cells, and that these platelets, as well as the blood, are washed out by the portal perfusion.

Other tissues which contained small but significant amounts of HT (more than $0.1 \mu \mathrm{g}$. $/ \mathrm{g}$.) were the hypothalamus, thyroid, and pancreas. It is interesting to note that Erspamer (1937) described enterochromaffin cells in the pancreas of certain mammals, including the hare, but that of the rabbit is not mentioned.

The effect of HT on the atropinized oestrous uterus of the rat is specifically blocked by LSD (Gaddum, 1953). After each assay sufficient LSD was added to the organ bath to abolish the response to the standard HT. With extracts of all the tissues mentioned above-blood, serum, spleen, mucosae, bone marrow, liver, lung, hypothalamus, thyroid and pancreas (except the "portal perfused" liver)-the activity was abolished by LSD. Thus, in these extracts, at least a very large proportion of the activity was probably due to HT. The tests on the liver samples, positive when the HT-equivalent was high and negative when it was low, suggest that there is some other uterus-contracting substance in these extracts.

In the extracts of each of the other tissues sampled, the activity was neither consistently abolished by LSD nor consistently resistant to this antagonist. The mean estimate for each of these tissues was never more than $0.1 \mu \mathrm{g}$. HT/g. It may be said that there was a trace of HT in the diaphragm, salivary glands and thymus, but in the heart, bladder, kidney, skeletal muscle and sciatic nerve no definite evidence for the presence of HT was obtained.

No uterus-stimulating activity was recorded from the adrenal extracts, but only an inhibitory effect on subsequent responses to HT. This observation results presumably from the incomplete destruction of the adrenaline by the enzyme preparation. The extracts became faintly red in colour, because of the relatively high concentration of adrenochrome.

\section{SUMMARY}

1. A survey of the HT content of acetone extracts of the various tissues of the rabbit has been made; the atropinized oestrous uterus of the rat was used for the assays.
2. The possible interference by adrenaline in the estimations was eliminated by treatment of the extracts with mushroom juice, which contains a polyphenoloxidase enzyme.

3. Significant amounts of HT were found in the spleen, various areas of the gut mucosa, blood and serum. The hypothalamus, the liver, and the bone marrow showed smaller amounts of HT. Other tissues (lung, thyroid, pancreas, and diaphragm) contained little HT, while in yet others HT was not detected (skeletal muscle, nerve, and adrenals).

4. The only test of specificity of the extract activity was by the effect of the extract on the LSD-treated uterus. LSD abolished the response, as it did that to HT, to active extracts of those tissues mentioned above, but not to extracts of mid-brain, olfactory bulbs, cerebellum and the tissues containing only traces of activity. These tissues must contain some other active substance.

This work was done during the tenure of a grant from the Carnegie Trust for the Universities of Scotland. I wish to thank Professor J. H. Gaddum and Dr. T. B. B. Crawford for their encouragement and interest.

\section{REFERENCES}

Amin, A. H. (1953). Ph.D. Thesis, University of Edinburgh.

Crawford, T. B. B., and Gaddum, J. H. (1954). J. Physiol., 126, 596.

Erspamer, V. (1937). Z. Anat. EntwGesch., 107, 574. (1942). Arch. exp. Path. Pharmak., 200, 60. (1952). Ric. sci., 22, 694.

(1954a). Ciba Foundation Symposium on Hypertension, p. 78. London: Churchill. (1954b). R. sci. Farmitalia, 1, p. 1.

- and Faustini, R. (1953). Naturwissenschaften, 40, 317.

__ and Sala, G. (1954). Brit. J. Pharmacol., 9, 31.

Feldberg, W., and Toh, C. C. (1953). J. Physiol., 119, 352.

Gaddum, J. H. (1953). Ibid., 121, 15 P.

Humphrey and Jaques (1954). Ibid., 124, 305.

Keilin, D., and Mann, T. (1938). Proc. Roy. Soc. (London), Series B, 125, 187.

Philpot, Flora J. (1940). J. Physiol., 97, 301.

Sumner, J. B., and Myrbäck, K. (1951). The Enzymes, Vol. 2, part 1, p. 456. New York: Academic Press Inc.

and Somers, G. F. (1953). Chemistry and Methods of Enzymes, 3rd ed., p. 240. New York: Academic Press Inc.

Udenfriend, S., and Weissbach, H. (1954). Fed. Proc., $13,412$. 